\title{
A Study on Guided Peer Feedback in Group Work in an English as Foreign Language Writing Class in China
}

\author{
Yougen Lou ${ }^{1}$, Honglian $\mathrm{Liu}^{2}$, Yangmei $\mathrm{Li}^{3}$, Jun Yang ${ }^{1,}$ * \\ ${ }^{1}$ School of Foreign Studies, Yangtze University, Jingzhou City, China \\ ${ }^{2}$ English Department, Jingzhou Experimental Middle School, Jingzhou City, China \\ ${ }^{3}$ English Department, Gong'an County No. 1 Middle School, Jingzhou City, China \\ Email address: \\ yangtzeu1@163.com (Jun Yang) \\ ${ }^{*}$ Corresponding author
}

\section{To cite this article:}

Yougen Lou, Honglian Liu, Yangmei Li, Jun Yang. A Study on Guided Peer Feedback in Group Work in an English as Foreign Language Writing Class in China. Education Journal. Vol. 5, No. 6, 2016, pp. 136-141. doi: 10.11648/j.edu.20160506.12

Received: August 11, 2016; Accepted: August 29, 2016; Published: November 18, 2016

\begin{abstract}
Peer feedback is a key to the quality of group work in foreign language writing classrooms. In order to better understand the use of peer feedback in writing foreign language (English) essays, a fifteen-week study was conducted by guided peer feedback in group work. 60 non-English-majored undergraduates in TG were randomly divided into 15 groups and one group member from every group was chosen as the leader of the group. This study chose three different tools - a checklist, a qualitative feedback sheet and a grading sheet, to guide peer feedback. Two English writing applied tests and an interview were utilized in this study to investigate the students' views and attitude toward the writing teaching method of guided peer feedback. We found: (1) the method of guided peer feedback in group work could improve non-English-majored undergraduate students' writing ability; (2) there were significant differences between males in CG and TG, and females in CG and TG; 3) non-English-majored undergraduate students in TG held the positive response for the combined writing instruction.
\end{abstract}

Keywords: Guided Peer Feedback, Group Work, EFL Writing Class

\section{Introduction}

Writing ability is important for undergraduate students in writing essays in examinations (College English Test 4 or 6) and the academic essays in their fields they majored. However, usually, Chinese non-English-majored undergraduate students' ability in writing English essays is not good. How to improve Chinese non-English-majored undergraduate students' ability in writing English essays is an important task for English teachers or English educators in China. In the framework of the task-based language learning, group work is regarded as a chief organizational form of learning (Ellis, 1994), because it enhance interaction and negotiation of meaning which can lead to language acquisition. However, the quality of group work varies widely in practice, and research into the means of group work enhancement is required urgently.

Peer feedback is a key to the interaction and language learning in groups. Rollinson (2005) explains, "In recent years, the use of peer feedback in ESL writing classrooms has been generally supported in the literature as a potentially valuable aid for its social, cognitive, affective, and methodological benefits" (p. 23).The present work focuses on the means of guidance in initiating effective peer feedback in group work.

\section{Literature Review}

Peer feedback can enhance language learners' awareness of their strong points and weak points, increase a sense of audience, encourage students' cooperative learning, and foster ownership (Tsui \& Ng, 2000). According to the study of Van den Berg et al. (2006), peer feedback in small group work is beneficial for learning if organized well. Many benefits of peer feedback have been claimed: providing an authentic audience to students; increasing students' 
motivation for speaking; enabling students to get different viewpoints; helping students learn to listen critically; helping students gain confidence in their speaking and encouraging students to use oral language skills (Mo, 2005).

Researchers (Yang et al., 2006) identify two main issues as a prerequisite for using successfully peer feedback in group work when implementing it: the size of peer feedback work group and the form of training. In peer feedback research, the size of groups varies, while pairs and groups of three and four are mainly utilized. Groups divided into three or four were used in some studies (Nelson \& Carson, 1998; Zhu, 2001) and it was found that group dynamics could strongly affect peer feedback groups' functioning. Especially in large classes, groups divided into three or four could help increase learners' interaction in class.

Methods to training students on how to provide effective peer feedback are also prone to variation. The students in the study of Tsui and $\mathrm{Ng}$ (2000) were only given broad categories when they needed to write comments. Zhu (2001) reported that students in the study of Zhu (2001) received training through watching videos.

As an important instructional activity, the research of peer feedback has covered many aspects. In foreign countries, most studies of peer feedback are in the field of writing instruction (Jan, Susanne \& Katrin, 2010). Nelson \& Carson's (1998) study investigated ESL students' perceptions of effectiveness in peer response groups. The findings of the study indicated that students preferred negative comments from their peers and preferred teacher's comments over those of their peers at the same time when they reviewed peers' essays (Lockhart \& Ng, 1993). This also shows that feedback does not lead to positive results automatically (Hattie \& Timperly, 2007). In spite of the popularity of peer feedback, it is difficult to describe clearly what comprises effective peer feedback (Marjo et al., 2010). Marjo et al. (2010) mainly discussed the specific circumstances under which particular types of peer feedback are beneficial for particular types of students learning, and one of their findings was that "peer feedback's psychometric qualities are improved by the training and experience of peer assessors." In China, Carson and Nelson (1996) investigated the interaction styles and reactions of Chinese students to peer feedback groups in ESL composition classes and indicated that the primary goal of Chinese students for groups was to maintain group harmony which affects the nature and types of interaction. This self-monitoring is not good for peer feedback. Mo (2005) conducted an empirical study among Chinese students and drew three conclusions: (1) peer review as a substitute for part of teacher feedback is as effective as teacher feedback; (2) most students are willing to get feedback from peers and regard it as useful; (3) Chinese students can make effective revision for peers, which is helpful to self-revision. Shulin $\mathrm{Yu}$ et al. (2016) revisited Chinese cultural issues in peer feedback in EFL writing, which were insights from a multiple case study.

The studies above did not involve in discussing that if the guided peer feedback in group work could improve foreign language (English) learners' writing ability in writing foreign language (English) essays !

The purposes of this study were to investigate that 1) Compared with CG, did peer feedback in group work help non-English-majored undergraduate students improve English writing applied ability? 2) Compared with $\mathrm{CG}$, after the training of peer feedback in group work, was there the significant difference on the writing scores between the two groups; 3) Was the method of peer feedback in group work beneficial to all undergraduate students of $\mathrm{TG}$ in English writing in this study? A comparative research method was used in this study.

\section{Methods}

\subsection{Subjects}

In September 2015, 120 second-year non-English-majored undergraduates in 4 classes from Yangtze University participated in this study. Among the 120 subjects, 68 were females and 52 males, average age 19 with Chinese as the main language. Their majors were horticulture, agriculture, plant protection, biological technology. All 120 non-English-majored undergraduates were taught by the same instructor during two years. All 120 students who had learned College English the first year. And the second year, 120 non-English-majored undergraduates were divided randomly into two groups. One group of 60 non-English-majored undergraduates was regarded as the Control Group (CG) with the traditional College English writing method and other 60 non-English-majored undergraduates were as Treatment Group (TG) with the method of guided peer feedback in group work. Both CG and TG, their level of education, family background, age, personality and life experiences and other factors were same, that was to say, their overall learning and cognitive abilities were almost equal. 60 non-English-majored undergraduates in TG were randomly divided into 15 groups, 4 non-English-majored undergraduates per group and one student chosen as the leader in every group to organize group members to discuss the peer feedback related to their writing.

\subsection{Instruments}

The instruments used in this study were three tools, two tests (the English writing test before the training of peer feedback in group work, the English writing test after the training of peer feedback in group work) and interviews.

Three tools were used to assist peer feedback: checklists, grading sheets and qualitative feedback sheets. They were based on Scaffolding Instruction of Constructivism. The students needed specific guidance in how to provide feedback so that they could understand what to focus on and how to make an evaluation. And the three forms of peer feedback are strongly operational on the content, organization, or vocabulary. The three tools represent different forms of guidance. The evaluation standard and what they focus on are different. Checklists focus on the content, grading sheets focus 
on the organization while qualitative feedback sheets focus on details.

All the 120 non-English-majored undergraduates were attended the English writing test (from College English Test, CET) to gain students' writing level in CG and TG before the experiment. And all the 120 non-English-majored undergraduates were attended the English writing test (from College English Test, CET) to gain students' changes in writing level in CG and TG after the experiment.

There were interviews with all 60 students in TG about improving the English writing skills through the method of peer feedback in group work and the harvest of learning English through this method. The instructor wrote down all interviews with all 60 students in TG about improving the English writing skills through the method of peer feedback in group work and the harvest of learning English through this method.

\subsection{The Measures of Peer Feedback}

When organizing peer feedback, the following measures (Hansen \& Liu, 2005) were used:

(1) Supplying purposeful and proper peer feedback sheets for a given task and purpose

This depended on whether the focus of each task was on the organization, content, or vocabulary.

(2) Helping students to be familiar with peer feedback procedures

Students were encouraged to ask questions related to peer feedback and teachers provided students some examples of peer feedback such as video.

(3) Instructing students to ask proper and right questions

Unless they were guided to ask proper questions and look for problematic issues, students may not make appropriate comments.

(4) Monitoring groups and peer feedback

The teacher took part in the activity as a peer or stayed in each group for some time to remind students of proper expressions.

\subsection{Data Collection and Analyses}

Before the research experiment (September 2015) and after the experiment (June 2016) two tests on English writing applied ability were conducted to compare changes between the two groups of students in English writing ability. In this study, the independent sample T-test and pair sample T-test were used for statistical analysis to the collected data. In order to find out the method of peer feedback in group work in English writing proved superior to the conventional teaching (such as students writing- teachers correcting) method, comparison of Means was adopted to compare two groups of non-English-majored undergraduate students' average scores of their pretest and after the experiment on the basis of samples. And the independent sample T-test was adopted to exanimate if there were significances between $C G$ and $\mathrm{TG}$ before the experiment and after the experiment.

\section{College English Writing Course}

College English course is required for undergraduate students as one of the compulsory courses in mainland China. The time for the college English writing course was 2 hours per week (in total 15 weeks). Horizon College English published by Foreign Language Teaching and Research Press was chosen as the textbooks for non-English-majored undergraduate students in their writing class. In total, there were ten units in Reading and Writing 2, and each unit included two passages (Text A and Text B) of the same topic and exercises. The method of traditional teaching writing for CG was that students in CG handed in the essays they wrote according to the writing instructor's requirement to the writing instructor return their essays after the instructor corrected some errors(such as grammatical errors, spelling errors ), some mistakes. And for TG, the instruction given in the writing classes included three steps. Firstly, the instructor would write down a topic related to Text A or Text B for non-English-majored undergraduate students to analyze or discuss among them before they wrote a essay. Non-English-majored undergraduate students in TG were given the information to write about a topic related to Text $\mathrm{A}$ or Text B, which was a scaffold for them from reading to writing. Secondly, 4 members in every group were received 4 first drafts of their essays as their homework to review, and they treated the drafts with the help of three tools: checklists, grading sheets and qualitative feedback sheets to assist peer feedback. Then in class, the instructor guided the 15 groups as the organizer. Brammer and Rees (2007) report, "The process of having students critique each other's papers has become commonplace in the composition classroom and in English composition textbooks" (p. 71). It was important for students' writing skills improved when requiring students to ask questions and provide feedback to one another in a whole class setting had a significant impact on student learning and the distribution of "cognitive work" between teachers and students (Frederiksen \& White, 1997;Herrenkohl\&Guerra, 1998). The leader in very group organized his/ her group to discuss or analyze the peer feedback from them about their first drafts and gave peer feedback or some suggestions on how to revise their drafts such as addition, deletion, substitution, permutation (or rephrasing), distribution (re-writing information in larger chunks), consolidation or re-ordering (moving) text (Min, 2006,p. 139). Finally, the first drafts they revised according to face-to-face peer feedback in group work to be the final product were handed to the instructor to correct errors such as grammar and polish.

\section{Results}

The findings in this study were shown in three parts. Part One was writing test results of CG and TG. Part Two was that whether there are significant differences between males and females, as a teacher-dominated approach with CG is compared with peer feedback in group work in writing class of TG. Part Three examined perceptions of the peer feedback in group work 
in writing class from non-English-major colleges in TG.

\subsection{Peer Feedback in Group Work and Writing}

As shown in Table 1, the impact of the method of writing instruction given by peer feedback in group work on non-English-major colleges' writing was measured by comparing writing tests' (CET 4) scores(total 105) between CG and TG in the pre-tests and post-tests. In the pre-tests, there was no significant difference between $\mathrm{CG}(\mathrm{M}=77.00, \mathrm{~S}=7.96)$ and $\mathrm{TG}(\mathrm{M}=76.80, \mathrm{~S}=9.29)$ in their writing tests, $\mathrm{P}=.876$. However, in the post-test, there was a significant difference between $\mathrm{CG}(\mathrm{M}=78.00, \mathrm{~S}=8.03)$ and $\mathrm{TG}(\mathrm{M}=81.18, \mathrm{~S}=9.95)$ in the writing test, $\mathrm{P}=.017$.

Table 1. Effects of the peer feedback in group work on non-English-major colleges'writing.

\begin{tabular}{lllllll}
\hline \multirow{2}{*}{ Groups } & Tests & \multicolumn{2}{l}{$\mathbf{C G}(\mathbf{N}=60)$} & \multicolumn{2}{l}{ TG(N=60) } & \multirow{2}{*}{ t } \\
\cline { 2 - 5 } & $\mathbf{M}$ & $\mathbf{S}$ & $\mathbf{M}$ & $\mathbf{S}$ & & \\
\hline Pre-test & 77.00 & 7.96 & 76.80 & 9.29 & .157 & .876 \\
Post-test & 78.00 & 8.03 & 81.18 & 9.95 & -2.461 & $.017 *$ \\
\hline
\end{tabular}

$\mathrm{M}$ stands for Mean; $\mathrm{S}$ stands for standard deviation; * $\mathrm{P}\langle .05 ; * * \mathrm{P}\langle .01$

\subsection{Results of the T-test About Males and Females in CG and $T G$}

As shown in Table 2, there were significant differences between males and females in CG and TG. Males $(\mathrm{P}=.002)$ suggested that there was the significant difference between $\mathrm{CG}$ and $\mathrm{TG}$, and females $(\mathrm{P}=.001)$ suggested that there was the. significant difference between $\mathrm{CG}$ and $\mathrm{TG}$ in their writing ability.

Table 2. Results of the t-test about males and females in CG and TG.

\begin{tabular}{llll}
\hline Gender & T(two-tailed) & Males & Females \\
\hline Probability & .002 & .001 \\
\hline
\end{tabular}

\subsection{Perceptions of Instructing Writing Through Peer Feedback in Group Work in Writing Class from Non-english-Major Colleges in TG}

The interview on the instruction method of peer feedback in group work in class from non-English-major undergraduate students in TG was administered to all subjects in TG at the end of the semester (January, 2016) to gain their responses for this integrated teaching method and to identify the possible benefits and problems of this method.

Among the 60 subjects in TG, 49 subjects told their students that the new combined teaching method of peer feedback in group work applied in their foreign language (English) writing instruction was really practical for them to improve their English writing skills and English writing ability through writing their drafts and their discussing the peer feedbacks in group work organized by the group's leader in class then revising their essays according to the peer feedback to be the final product to the instructor correct or polish their essays; 11 subjects in TG indicated that the new teaching method of peer feedback in group work in English writing class showed them a new insight on how to write an English essay from reading articles or papers written by others to how to revise their first drafts according to peer feedbacks or suggestions because of their first drafts discussed in the group work in class, through the new teaching writing method applied in writing their English essays, they knew how to write correct sentences in essays, how to organize the essays and how to provide proper peer feedbacks for their peers' essays .

\section{Discussion}

This paper wants to look for the answers to the three questions. One of the purposes in this study is to know if the writing instruction through peer feedback in group work in class can improve non-English-majored colleges' writing ability. Subjects' improvement in writing ability shows the important role of peer feedback in group work played in their writings.

Through results in Table 1, we could know that after learning, both writing scores in CG and TG were improved, but the writing scores in TG were higher than that in $\mathrm{CG}$, it means that the new teaching writing method of peer feedback in group work can improve non-English-majored colleges' writing ability in TG after they were trained by the new method. The results in this study agrees with the results in some research has shown that peer feedback improves learning (e.g., Li et al., 2010; Topping, 2000; Topping \& Ehly, 2001; Xiao \& Lucking, 2008). The method of peer feedback in group work encouraged students to discuss and analyze their essays from new ideas from peers to improve their writing ability. Linn (2000) writes, "Encouraging students to analyze and build on ideas from peers can introduce new perspectives and motivate students to reconsider their own ideas" (p. 788).

After instruction and training by the model of peer feedback in group work, male and female non-English-major undergraduate students in TG successfully learn to provide the proper feedbacks for essays from peers and devise their essays according to peer feedbacks about their essays, they show better in writing ability, compared with male and female non-English-major colleges in CG. And there are significant differences between Males and Females in CG and TG. The results could be explained by the research, for example, Hovardas et al. (2014) cite research suggesting that "sharing a frame of understanding" (p. 149) about a problem with one's peers might make peer suggestions more accessible and more readily actionable than suggestions from a teacher (Black \& William, 2004; Bloxham \&West, 2004). Male and female non-English-major undergraduate students in TG could have the opportunity to discuss the problems in their essay, which would provide chances for them to improve their writing ability.

Non-English-major colleges in TG generally holding positive response for the peer feedback in group work training program suggest that the combination of peer feedback with 
the group work into regular EFL curriculum is a worthy try. Non-English-majored undergraduate students need practice writing and revising more academic papers related to their majors, the method ofpeer feedback in group work is practical method for them to learn how to write and how to revise their essays with the help of peer feedback in group work in class and apply the writing skills and revising skills they learn to practice writing essays and academic papers. Although subjects in TG could learn the peer feedback in group work, they also need the help from teaches. A teacher in the writing class could help guide or organize the students in class and provide some help for students such as having difficulties in providing peer feedbacks. It is common that some students could be shy even tense about the face-to-face peer feedbacks, which might be related to the cultural factor. For Chinese students, research has found that the traditional Chinese cultural issues, such as collectivism and group harmony, the concept of "face," and power distance could exert negative influence on students' engagement with or participation in peer feedback (Carson and Nelson 1996; Hu andLam 2010; Hyland 2000; Nelson and Carson 2006).

\section{Limitations and Suggestions for Further Research}

Though the present study has provided a survey on the guided peer feedbacks in group work among the non-English-majored undergraduate students, there are still some limitations of the study. Having the limitations in mind, suggestions for further research, therefore, can be put forward at the same time in order to achieve a lot thorough understanding of the non-English-majored undergraduate students' guided peer feedbacks in group work.

Firstly, being time limitation (only 15 weeks) and other practical restrictions such as the subjects in the study consisted of only120 non-English-majored undergraduate students in one university need to be broadened in further research.

Secondly, the instruments used to investigate the non-English-majored undergraduate students' guided peer feedbacks in group involve three tools to measure peer feedbacks, tests and interviews. The study would be much better, if it were combined with other instruments such as observation, verbal report. More instruments should be used in investigating in the further research.

Finally, participates in this study were the non-English-majored undergraduate students in only one university. Results of other subjects' guided peer feedbacks in group work in English writing such as English-majored undergraduates and graduates, we need further research.

Despite of the restraints of the study, it is hoped that it can offer some guidelines for further research on non-English-majored undergraduate students' guided peer feedbacks.

\section{References}

[1] Black, P., \& Wiliam, D. (2004). The formative purpose: Assessment must first promote learning.

[2] Yearbook of the National Society for the Study of Education, $103,20-50$.

[3] Bloxham, S., \& West, A. (2004). Understanding the rules of the game: Marking peer assessment as a medium for developing students' conceptions of assessment. Assessment \& Evaluation in Higher Education, 29(6), 721-733.

[4] Brammer, C. \& Rees, M. (2007). Peer review from the students' perspective: Invaluable or invalid? Composition Studies 5(2), 71-85.

[5] Carson, J., \& Nelson, G. (1996). Chinese students' perception of ESL peer response group interaction. Journal of Second Language Writing, 5, 1-19.

[6] De Grez, L., Valcke, M., \& Berings, D. (2010). Peer assessment of oral presentation skills. Procedia Social and Behavioral Sciences, 2, 1776-1780.

[7] Ellis, R. (1994). The study of second language acquisition. Shanghai: Shanghai Foreign Language Education Press.

[8] Frederiksen, J. R., \& White, B. Y. (1997). Cognitive facilitation: A method for promoting reflective collaboration. Proceedings of the Second International Conference on Computer Support for Collaborative Learning (pp. 53-62). Toronto: University of Toronto.

[9] Hansen, J. G., \& Liu, J. (2005). Guiding principles for effective peer response. ELT Journal, 59(1), 31-38.

[10] Hattie, J., \& Timperley, H. (2007). The power of feedback. Review of Educational Research, 77, 81-112.

[11] Herrenkohl, L. R., \& Guerra, M. R. (1998). Participant structures, scientific discourse, and student engagement in fourth grade. Cognition and Instruction, 16(4), 431-473.

[12] Hovardas, T., Tsivitanidou, O. E., \& Zacharia, Z. C. (2014). Peer versus expert feedback: An investigation of the quality of peer feedback among secondary school students. Computers \& Education, 71, 133-152.

[13] Hu, G., \& Lam, S. T. E. (2010). Issues of cultural appropriateness and pedagogical efficacy: Exploring peer review in a second language writing class. Instructional Science, 38, 371-394.

[14] Hyland, F. (2000a). ESL writers and Feedback: Giving more autonomy to students. Language Teaching Research, 4(1), 3354.

[15] Jan, W. S., Susanne, N., \& Katrin, D. (2010). Peer feedback content and sender's competence level in academic writing revision tasks: Are they critical for feedback perceptions and efficiency? Learning and Instruction, 20, 291-303.

[16] Li, L., Liu, X., \& Steckelberg, A. L. (2010). Assessor or assesse: How student learning improves by giving and receiving peer feedback. British Journal of Educational Technology, 41(3), 525-536.

[17] Linn, M. C., \& Slotta, J. D. (2000). WISE science. Educational Leadership, 58(2), 29-32. 
[18] Lockehart, C., \& Ng, P. (1993). How useful is peer response? Perspectives 1, 17-29.

[19] Nelson, G. L., \& Carson, J. G. (1998). ESL students' perceptions of effectiveness in peer response groups. Journal of Second Language Writing, 7, 113-131.

[20] Nelson, G., \& Carson, J. (2006). Cultural issues in peer response: Revisiting 'culture'. In K. Hyland \& F. Hyland (Eds.), Feedback in second language writing: Contexts and issues (pp. 42-59). New York: Cambridge University Press

[21] Min, H. T. (2006). Training students to become successful peer reviewers. System, 293-308.

[22] Mo, J. H. (2005). An exploratory study of conducting peer review among Chinese college students. CELEA Journal, 28(6), 43-48.

[23] Rollinson, P. (2005). Using peer feedback in the ESL writing class. ELT Journal 59(1), 23-30.

[24] Topping, K. (2000). Peer assisted learning: A practical guide for teachers and parents. London: New York, Cassell.
[25] Topping, K. J., \& Ehly, S. W. (2001). Peer assisted learning: A framework for consultation. Journal of Educational and Psychological Consultation, 12, 113-132.

[26] Tsui, A. B. M., \& Ng, M. (2000). Does secondary L2 writers benefit from peer comments? Journal of Second Language Writing, 9(2), 147-170.

[27] Van den Berg, I., Admiraal, W., \& Pilot, A. (2006). Design principles and outcomes of peer assessment in higher education. Studies in Higher Education, 31, 341-356.

[28] Xiao, Y., \& Lucking, R. (2008). The impact of two types of peer assessment on students' performance and satisfaction within a Wiki environment. Internet and Higher Education, 11, 186-193.

[29] Yang, M., Richard, B., \& Yu, Z. (2006). A comparative study of peer and teacher feedback in a Chinese EFL writing class. Journal of Second Language Writing, 15, 179-200.

[30] Zhu, W. (2001). Interaction and feedback in mixed peer response groups. Journal of Second Language Writing, 10(4), 251-276. 